\title{
Analysis of Stallholder Farmers' Participation in Agricultural Extension Services in Yayo and Hurumu Districts of Oromia, South-West Ethiopia
}

\author{
Dessalegn Eticha \\ Lecturer, Department of Economics, College of Business and Economics, Wollega University \\ P.O. Box 395, Nekemte, Ethiopia
}

\begin{abstract}
This study examines farmers' participation and applicability of agricultural extension service demonstration in Yayo and Hurumu districts of Oromia, South-West Ethiopia. Specifically, it aims to evaluate factors determining households' participation in agricultural extension service; applicability of the extension service field demonstration; and major sources of information from where rural households get information about the service. The primary data was collected from 143 household heads selected based on systematic random sampling from four Kebeles, and interview conducted with 10 key informants. Analysis is made by descriptive and inferential statistics. Ordered logit econometric model is used with robustness test. Marginal effect is used to interpret the effect of explanatory variables on the dependent variable. Result of the study reveals that about $15.3 \%$ of literate households frequently participate in the extension service while only $4.23 \%$ of illiterate households fall under the category of frequently participating in the service. Factors determining households' participation in extension service include; age, sex, farming experience, family size, economic status, experience in extension service, DAs contact with farmers, DAs politeness, and farmers' access to social networks. Among these, except age of household which is negatively related to the degree of participation in extension service, all other variables are positively influencing households' participation in the extension service. The study also indicates that applicability of the field demonstration through farmers' farm visit, demonstration at FTCs, and model farmers' approach of scaling-up best practices are ineffective. The main sources of information through which rural households get information about extension service include development agents, neighbors/relatives, social networks, Kebele administration, and mass media. But, about $90 \%$ of the sampled households argued that the contribution of NGOs and model farmers' in information dissemination and technology transfer has been poor. The policy implication is that government has to make the extension service delivery approach more demand driven and pluralistic where different multi-extension service providers such as farmers' union, NGOs and private sectors can contribute their part. To promote participation of private and NGOs particularly local NGOs, government better design legal frameworks through which stakeholders could involve in providing agricultural extension service.
\end{abstract}

Keywords: Extension service, FTCs, FFS, Model farmers, Social networks.

DOI: $10.7176 / \mathrm{JESD} / 12-21-02$

Publication date: November $30^{\text {th }} 2021$

\subsection{INTRODUCTION}

Development experiences show that successful economic transformation vitally depends on agricultural development. In fact, countries of the world have emphasized on agricultural development goals of eradicating poverty and ensuring sustainable development (FAO, 2017). In Ethiopia, about $85 \%$ of the people are living in rural areas depending on agriculture for their livelihood. The sector accounts for more than $40 \%$ of national GDP, $90 \%$ of exports, $83 \%$ of the country's labor force, and used as source of income for more than $90 \%$ of the poor (IFPRI, 2010; WB, 2015). With the downfall of Dergue regime in 1991, government introduced a radical shift in major policies including agriculture and announced extensive economic reforms such as market liberalization, privatization of state-owned enterprises, and structural adjustment programs (IFPRI, 2010). Agricultural Development-Led Industrialization (ADLI) policy was adopted with Participatory Demonstration and Training Extension System (PADETES) in the mid of 1990s. The recent extension service approach known as Participatory Extension System (PES) was developed in 2010. Nevertheless, the agricultural extension in Ethiopia is highly supply driven and production oriented characterized by weak coordination of extension actors (Leta et al., 2017). In addition, it has been non participatory in nature where marginalized group and poor farmers have not been included in the planning, implementation and evaluation activities of the extension service (Adugna, 2013). In effect, the overall agricultural growth performance has not been realized in line with the set poverty-reduction goals.

\subsection{Statement of the Problem}

In Ethiopian, Participatory Extension System (PES) was introduced to ensure extension service provision through disseminating information, scaling-up best practices, incentivizing production of high value crops, and expanding 
irrigation and natural resource conservation (MoARD, 2010; Adugna, 2013; Mengistie and Belete, 2015; Yenesew et al, 2016). However, due poor extension service provisions, food insecurity has been among the major challenges of the country. The extension packages have focused on package orientation; stress on increased use of chemical inputs, and increased deployment of extension personnel (Berhanu, 2009). According to Leta et al. (2017), the service approach is dominated by "public agricultural extension" as the main "development actor" in providing agricultural advisory service to farmers through district agriculture and rural development office. In this regard, different researches were conducted to find the problem of public agricultural extension service. But, the researcher has identified some research gaps in the area of agricultural extension service delivery approach. Some studies focused on the role of agriculture in creating employment opportunity (Bieri and Sancar, 2009), and investigating role of agricultural extension services in improving production and nutrition of women farmers (Huria, 2014). The study conducted by Wasihun et al (2014) focused on the perception disparity level between male and female farmers, and to determine the best predictors of farmers perceived level of participation in the extension service. The study conducted by Kaleb (2016) was limited to the scaling-up of model farmers' best practices alone without considering other approaches being implemented for the applicability of field demonstration. A recent study conducted by Frafis focused on factors affecting women's participation in agricultural extension services but tried to link with household income and also used interview as a tool for data collection (Firafis, 2016). More recently, Leta, et al. (2017) conducted an assessment on agricultural extension system in Ethiopia focusing on operational setup, challenges and opportunities. The data was collected through interview with sample households, and also output of the research was qualitatively analyzed. Hence, this study aims to bridge the research gaps related with an assessment of rural households' participation in agricultural extension service using both quantitative and qualitative analysis.

\subsection{Objectives of the Study}

The general objective of this study was to analyze smallholder farmers' participation in agricultural extension services in Yayo and Hurumu Districts of Oromia whereas specific objectives include;

1) To identify major determinants of rural households' participation in agricultural extension services;

2) To evaluate applicability of the public agricultural extension service field demonstration in the districts;

3) To identify major sources of information from where rural households get information about the extension services.

\subsection{MATERIALS AND METHODS}

\subsection{Study Area}

Yayo and Hurumu are among Districts of Ilu Aba Bora zone of Oromia, located to South-West Ethiopia. The districts are found at the center of the high way road from Addis Ababa to Jima-Bedele, and to Matu, then to Gambela Regional State. The districts remain remnant habitat for wild coffee (Coffee Arabica) which is important for conservation of the genetic diversity of natural coffee known for great coffee production in the country. Coffee in the districts alone contributes for around $70 \%$ of households' income in the area. Yayo Biosphere Reserve, which plays a key role in conservation of natural and cultural landscape. For its international importance, the United Nations Educational, Scientific and Cultural Organization (UNESCO) has recognized the Biosphere Reserve since 2010.

\subsection{Sample Size and Strategy}

The study was conducted in four Kebeles of Yayo and Hurumu districts. The total number of target households in the Kebeles was estimated to be 1,646. To determine the required sample size, the formula developed by Yamane T (1967) was used. Systematic random sampling was applied to select the sample respondents as almost all households are involved in farming activities. Based on the mathematical formula (with $95 \%$ confidence level) and assumed precision level $(e)$ of $8 \%=0.08$, the sample size $(n)$ is about 143 household heads who were selected and filled the questionnaire.

$\mathrm{n}=\frac{\mathrm{N}}{\left[1+\mathrm{N}\left(e^{2}\right)\right]}=\frac{1,646}{\left[1+1,646\left(0.08^{2}\right)\right]}=\frac{1,646}{[11.53]}=\underline{\underline{143}}$

Where $\mathrm{n}=$ Sample size; $\mathrm{N}=$ Total household size; $\mathrm{e}=$ precision level. Thus, the determined sample size of households who filled the questionnaire was 143, which was then distributed to each Kebeles based on the proportion of respective number of households in each Kebele.

\subsection{Data Sources and Collection Techniques}

The study is largely based on primary data collected through questionnaire from 143 sample households and interview conducted with 10 key informants. Open and close ended questionnaire was distributed to the 
respondents and all the copies distributed were retrieved. In addition to questionnaire, to evaluate role of concerned government and nongovernmental actors in the extension service, semi-structured interview was conducted with purposively selected key informants; two officials from Agricultural and Rural Development Office of both districts; four development agents (one from each Kebele); two officers from NutriHAF/ECFF project, and two health extension agents.

\subsection{Method of Data Analysis}

Descriptive and inferential statistics were used to analyze the data with explanatory sequential mixed research design approach. The study incorporates both quantitative and qualitative aspect as using combination of the two provides better understanding of the problem (Creswell, 2007).

\subsubsection{Model Specification}

In this study, logistic regression model was applied since it is used to model categorical outcome variables. The model is widely used for issues relating to expectations, participation and for other cases with measurement of ordinal/ranked in nature (Anderson et al., 2009; Amemiya, 1981). Based on its qualitative nature, ordered logit model was used for frequency of household's participation in extension service. The dependent variable is measured using 3 point likert-scale. In ordered logit, $F(x)$ is specified as the logistic distribution function given by: $F(x)=\frac{\exp (\mathrm{x})}{[1+\exp (\mathrm{x})]} \ldots \ldots \ldots$

Given the values of $Y$ represent ordered items, and $Y \mathrm{i}$ the level of participation of households, $\mathrm{Y}_{\mathrm{i}}$ is defined as:

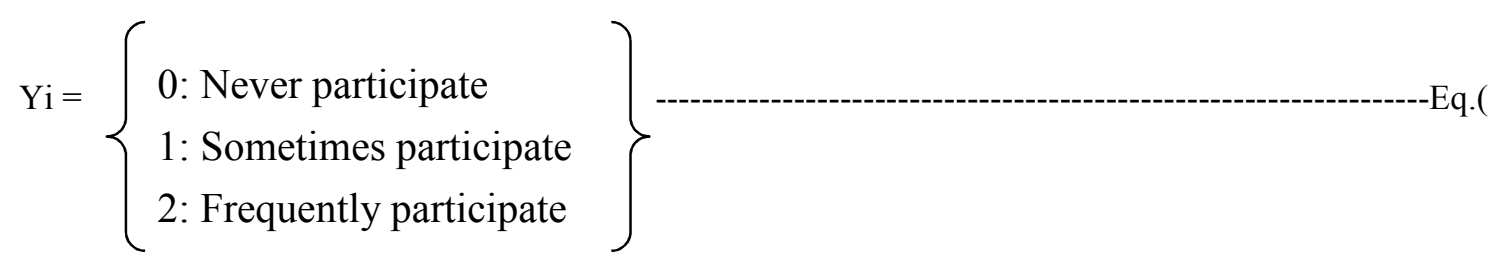

$Y$ is categorical where a higher value means more participating in the service, and there exists a known number $(\mathrm{m})$, such that: $\mathrm{P}[\mathrm{yi} \in\{0,1,2 \ldots \mathrm{m}\}]=1$ Eq.(3)

So, the model for latent (unobserved) variable is given by: $Y_{i}^{*}=\alpha+\beta_{i} X_{i}+\varepsilon$

Where, $\mathrm{Y}_{\mathrm{i}}{ }^{*}$ is latent (unobserved) measure of frequency of households participation, $X_{i}$ is the vector of explanatory variables, $\alpha$ and $\beta_{i}$ coefficients to be estimated, and $\varepsilon$ is an error term. Thus, the defined categorical variable $Y i$ (frequency of participation) is determined from the model as:

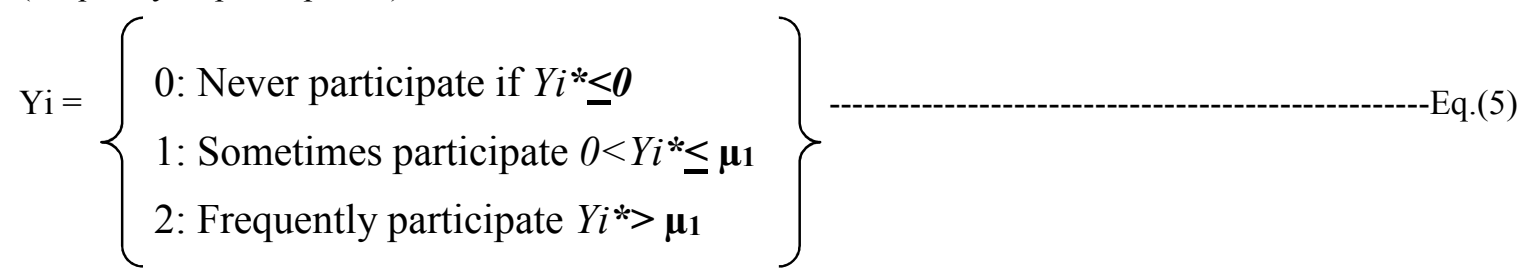

Where, $\mu_{1}$ is a set of thresholds of the participation gap to be estimated with the parameter vector $\alpha$ and $\beta$. The probability associated with the coded responses of an ordered probability model is given by:

$\operatorname{Pr}(\mathrm{Yi}=\mathrm{j})=\operatorname{Pr}\left(\mu_{\mathrm{j}-1}<\mathrm{Yi}^{*} \leq \mu_{\mathrm{j}}\right)=\operatorname{Pr}\left(\mu_{\mathrm{j}-1}<\left[\alpha+\beta_{\mathrm{i}} \mathrm{X}_{\mathrm{i}}+\varepsilon\right] \leq \mu_{\mathrm{j}}\right)$

Where, $j$ represents the ranked value of participation in the extension service. The random error ' $\varepsilon$ ' is such that:

$\operatorname{Pr}(\mathrm{Yi}=\mathrm{j})=\operatorname{Pr}\left(\mu_{\mathrm{j}-1}<Y i^{*} \leq \mu_{\mathrm{j}}\right)=\mathrm{F}\left(\mu_{\mathrm{j}-} \alpha-\beta_{\mathrm{i}} \mathrm{X}_{\mathrm{i}}\right)-\mathrm{F}\left(\mu_{\mathrm{j}-1-1}-\alpha-\beta_{\mathrm{i}} \mathrm{X}_{\mathrm{i}}\right)---\mathrm{-}$

\subsection{Variables Definition and Measurements}

In this study, frequency of households' participation in extension service is the dependent variable whereas list of explanatory variables expected to significantly determine dependent variable are presented in the following table. 
Table 1: Definition of explanatory variables with measurement and expected sign.

\begin{tabular}{|l|l|l|c|}
\hline \multicolumn{1}{|c|}{$\begin{array}{c}\text { Independent } \\
\text { Variables }\end{array}$} & \multicolumn{1}{|c|}{ Definition of variables } & \multicolumn{1}{|c|}{ Measurement of the variables } & Sign \\
\hline Sex & Sex of the household head & Male=1, Female $=0$ & + \\
\hline Age & Age of the household head & Years of age (continuous) & \pm \\
\hline Literacy & Hhs literacy (can read and write) & Yes=1, No=0 & + \\
\hline Experience & Farming experience of hh head & Farming experience (in years) & + \\
\hline Econ. Status & Economic status of the hh head & $\begin{array}{l}\text { 1=better off, 2=middle income } \\
\text { 3=poor }\end{array}$ & \pm \\
\hline Family size (no.) & Number of family members & Total family Members (continuous) & + \\
\hline $\begin{array}{l}\text { DAs contact with } \\
\text { household head }\end{array}$ & $\begin{array}{l}\text { DAs contact with farmer household } \\
\text { (per year) }\end{array}$ & $\begin{array}{l}\text { Number of times household head } \\
\text { visited by DAs (per year). }\end{array}$ & + \\
\hline $\begin{array}{l}\text { Experience in } \\
\text { Extension service }\end{array}$ & $\begin{array}{l}\text { Households experience of } \\
\text { participation in extension }\end{array}$ & $\begin{array}{l}\text { Years of extension service experience } \\
\text { (per year). }\end{array}$ & + \\
\hline $\begin{array}{l}\text { Farmers social } \\
\text { network }\end{array}$ & $\begin{array}{l}\text { Hhs access to social networks such } \\
\text { as Iddir, Iqoub, Dabo, Mahiber, etc. }\end{array}$ & Yes=1, No=0 & + \\
\hline DAs behavior & DAs behavior whether polite or not & Polite $=1$, Not polite=0 & + \\
\hline Access to credit & Hhs access to credit service & Yes=1, No=0 & + \\
\hline
\end{tabular}

Source: Author's definition, 2018

\section{RESULT AND DISCUSSION}

\subsection{Descriptive Analysis}

\subsubsection{Socio-economic Characteristics of Respondents}

The total number of farmer households included in the study was 143 of which $33(23.08 \%)$ of them were female and $110(76.92 \%)$ male headed households. The proportion is consistent with women household heads share of total farmer households in Ethiopia which is about 25 percent (FAO, 2011). Table 2 below presents descriptive statistics of respondents' background information where mean estimation and chi-square test is used to assess for variables expected to determine frequency of households' participation in agricultural extension service.

Table 2: Background information of the respondent households

\begin{tabular}{|c|c|c|c|c|c|}
\hline & Variables & Mean & Std. Err. & $\chi^{2}$ & P-value \\
\hline \multirow{10}{*}{ 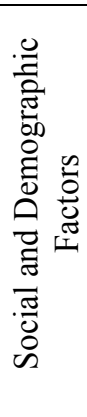 } & Frequency of participation & .9650 & .0402 & & \\
\hline & Sex of the household & .7692 & .0353 & 2.87 & 0.090 \\
\hline & Age of the household & 46.87 & 1.244 & 9.10 & 0.002 \\
\hline & Marital status of the household & 1.657 & .0952 & 0.57 & 0.450 \\
\hline & Economic status of the household & 2.202 & .0574 & 3.91 & 0.047 \\
\hline & Farming experience of household & 26.04 & 1.264 & 4.48 & 0.034 \\
\hline & Number of household size & 4.699 & .1645 & 3.96 & 0.046 \\
\hline & Number of active family members & 3.069 & .1337 & 2.25 & 0.134 \\
\hline & Access to social network & .8671 & .0284 & 3.43 & 0.064 \\
\hline & Experience in extension service & 10.04 & .6433 & 17.93 & 0.000 \\
\hline \multirow{5}{*}{ 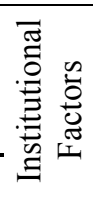 } & DAs Politeness (behavior) & .2377 & .0357 & 4.46 & 0.034 \\
\hline & Labour division status & .2097 & .0341 & 0.50 & 0.481 \\
\hline & Access to transportation & .1608 & .0308 & 0.28 & 0.596 \\
\hline & DAs farmers' farm visit (contact) & 2.678 & .2059 & 21.75 & 0.000 \\
\hline & Households access to irrigation & .6433 & .0401 & 1.04 & 0.308 \\
\hline
\end{tabular}

Source: Field survey, 2018

The average age of household heads is about 46.9 indicating the selected households have good experience in farming activities. The average farming experience (26.04 years) is almost half of the average age of the respondents. It is similar to the study conducted by Berhanu et al. (2014) where mean farming experience was about 22.7 years. The mean family size is 4.7 which reflect that rural farming communities have greater family size due to lack of awareness and family planning programs. Development Agents (DAs) contact with farmers was considered as one of the continuous variables. The mean average of DAs farmer households' farm visit is about 2.67 with standard deviation of 2.46. The other variable considered was the number of active working force within the family members which is found to be 3.06. This shows that study area has with potential working age (youth). Economic status of sample households indicate that 22(15.4\%), 70(48.9\%), and $51(35.7 \%)$ of them fall under the category of better-off, middle income and poor economic status respectively which was considered adequate to get reliable information about households falling within the category of each economic status. Nearly half (48.9\%) of respondents are middle income households. Since respondents were randomly selected from each category 
based on the proportion, farmers in the study area could be in a good economic status compared to other parts of the country. Coffee and other cash crop production with the good climate condition in the area has contributed much for this fact. However, to generalize, it needs to conduct in-depth research on food security status of the rural households in the area.

The following table 3 presents degree of households' participation in public agricultural extension service. The data reveals that majority of the respondents argue that they sometimes participate in the extension service provision. Nevertheless, only $9.79 \%$ of them fall under the category of frequently participating whereas $14(9.79 \%)$ respondents fall under the category of never participated in the service indicating that there is a room to make the extension service more participatory.

Table 3: Frequency of households' participation in agricultural extension service

\begin{tabular}{|l|c|c|c|}
\hline Frequency of household participation in the agricultural extension services & Freq. & Percent & Cum. \\
\hline Never participate & 19 & 13.29 & 13.29 \\
\hline Sometimes participate & 110 & 76.92 & 90.21 \\
\hline Frequently participate & 14 & 9.79 & 100.00 \\
\hline Total & 143 & 100.00 & \\
\hline
\end{tabular}

Source: Field survey, 2018

\subsection{Econometric Result}

\subsubsection{Model Fitness}

To decide whether association between response variable (frequency of participation) and each term in the model is statistically significant, the p-value is compared with the significance. The null hypothesis is that the term's coefficient (independent variables) is equal to zero which indicates that there is no association between the variable and the response variable. A significance level of $>$ or $=0.05(5 \%)$ was considered as the minimum risk of concluding an association exists. Thus, $\mathrm{P}$-value $<\alpha$ : if the association is statistically significant. To interpret the effect of explanatory variables on dependent variable, marginal effect at mean which is commonly used as the means of interpreting associations between response variable and each term is applied. It measures a unit change effect of each independent variable on the dependent variable holding all other explanatory variables at their respective means. Different tests were done to check the model fitness and its correctness. The logistic regression model correlation between independent variables was checked to avoid severe multi-co linearity problem. To test normality of each variable, kernel density estimate approach was used and they were normal. It is also checked that yhat is significant and yhatsq is insignificant in the model. Though Breusch-Pagan/Cook-Weisberg test for heteroskedasticity was commonly used in linear regression model, for reliability purpose, heteroskedasticity was also checked. Here, the null hypothesis was assumed to be constant variance, and alternative hypothesis with heteroskedasticity. The test result was with chi2 $(1)=2.80$ and Prob $>$ chi $2=0.0941$. So, since chi-square is insignificant, the researcher decided to reject alternative hypothesis and concluded that there is no heteroskedasticity problem.

\subsubsection{Determinants of Rural Households Participation in Agricultural Extension Service}

In this research, explanatory variables which were expected but could not significantly determine were omitted from the regression output. Some of these include household head's marital status, literacy, religion, access to credit, occupation, access to land, membership to cooperatives, and others. The model is strong in explaining the dependent variable as Prob $>$ chi $2=0.0000$. 
Table 4: Ordered logit result for households' degree of participation in extension service

\begin{tabular}{|c|c|c|c|c|c|c|}
\hline Ordered logistic regression & & & & $\begin{array}{l}\text { Aber of obs }= \\
\text { R chi2 }(14)= \\
\text { Prob }>\text { chi }^{2}= \\
\text { Pseudo } R^{2}=\end{array}$ & & $\begin{array}{r}143 \\
148.02 \\
0.0000 \\
0.7420 \\
\end{array}$ \\
\hline $\begin{array}{l}\text { Degree of participation in } \\
\text { extension service }\end{array}$ & Coef. & Std. Err. & $\mathrm{Z}$ & $\mathrm{P}>\mathrm{Z}$ & \multicolumn{2}{|c|}{ [95\% Conf. Interval] } \\
\hline Family size (no.) & .70156 & .344278 & 2.04 & $0.042 * *$ & .0267910 & 1.37634 \\
\hline DAs misbehavior (1=yes) & -2.2319 & 1.06538 & -2.10 & $0.036 * *$ & -4.32008 & -.143886 \\
\hline Labor division $(1=$ yes $)$ & .843284 & 1.13745 & 0.74 & 0.458 & -1.38608 & 3.07265 \\
\hline Transportation access ( $1=$ yes $)$ & -.657977 & 1.17574 & -0.56 & 0.576 & -2.96239 & 1.64644 \\
\hline Farmers social network $(1=$ yes $)$ & 2.45050 & 1.2885 & 1.90 & $0.057 *$ & -.074903 & 4.97591 \\
\hline Extension experience (in years) & .487828 & .115954 & 4.21 & $0.000 * * *$ & .260562 & .715094 \\
\hline Sex of household head $(1=$ male $)$ & 2.07403 & 1.22729 & 1.69 & $0.091 *$ & -.331430 & 4.47949 \\
\hline Farming experience (in years) & .218698 & .1023932 & 2.14 & $0.033 * *$ & .018011 & .419385 \\
\hline DAs contact to farmer(per yr) & 1.51433 & .328155 & 4.61 & $0.000 * * *$ & .871162 & 2.15750 \\
\hline Age of respondent( in years) & -.377192 & .124973 & -3.02 & $0.003 * * *$ & -.622134 & -.132250 \\
\hline Econ. status of household & & & & & & \\
\hline Middle income & 1.80806 & 1.21736 & 1.49 & 0.137 & -.577915 & 4.19404 \\
\hline Poor & 2.8278 & 1.42723 & 1.98 & $0.048 * *$ & .030487 & 5.62511 \\
\hline Access to irrigation $(1=$ yes $)$ & -.863888 & .867769 & -1.00 & 0.319 & -2.56468 & .836907 \\
\hline Active family members (no.) & -.619665 & .398457 & -1.56 & 0.120 & -1.40062 & .161296 \\
\hline /cut1 & -2.76322 & 3.17753 & & & -8.99108 & 3.46463 \\
\hline /cut2 & 9.47073 & 3.81975 & & & 1.98414 & 16.9573 \\
\hline
\end{tabular}

Table 4 depicts factors determining households' participation in the extension service. The major significantly determining factors include DAs contact with farmers, households' age, sex, farming experience, family size, economic status, extension service experience, development agents' behavior, and farmers' access to social networks.

* DAs contact with farmers: In this study, DAs farmers' firm visit is found to positively determine frequency of farmers' participation in the agricultural extension service. The coefficient with positive sign indicates that, with an increase in the contact between DAs and farmers, households' participation in the extension service is more likely to occur (from a shift from never participate to frequently participate). This is consistent with studies which found that development agents' contact has positive relation with farmers' participation in extension service (Berihun et al., 2014; Umar et al., 2015; Elias et al., 2015; Frafis, 2016).

* Age: Age refers to the age of household heads which is continuous and measured in terms of years. In most cases, farmer's age is positively associated with the participation in the extension service. This is likely because older farmers tend to boost their farming production and productivity through adopting and experiencing modern farming systems. However, result of this finding indicates that age of the household heads has negative association with the degree of farmers' participation in the extension service. The higher the age, households are less likely to be in higher categories of participation in the service. The reason could be the fact that increases in age reduces farmers' capability to involve in crop production as the area is cash crop area such as coffee which needs more labor force. The information from DAs through interview also pointed that there are households who do not take part in the training and other extension service provisions due age.

* Farming experience: Farming experience denotes the total number of years the household head has been involved in the farming activities. As expected, this finding shows that farming experience has positive link with the participation in the extension services. The more a farmer is experienced in farming activities, the more he/she is participating in the extension services indicating that more experienced farmers possess greater knowledge and skills about the service. It is consistent with studies which found positive association between farming experience and degree of participation in the extension service (Soltani et al., 2011; Umar et al., 2015; Lemlem, 2016).

* Sex: Sex of the household head was assumed to be binary response where 1 represents male and 0 represents female heads. Mostly, sex of the household heads has an impact on farmers of participation in the extension service where male heads are more participating in the service than their women counter parts. Result of this 
study also shows that men household heads are more likely to participate in the service than women. This is consistent to the study carried out in Pudukkottai district of India which found that social customs imposed barriers to achieving gender equity in extension service participation (Benson and Jafry, 2013). The possible reason for this could be the fact that gender gap affects farmers' access to labor, land, information, and other farming inputs.

* Economic status: Economic status is among categorical variables positively determining households' participation in extension service. Consistent to findings such as Asres et al., 2014; Birhanu et al., 2014; Elias et al., 2015, this study reveals that there is direct relationship between farmers' economic status and participation in extension services. Taking better-off as base category, the more the economic status of households the more the probability that he/she participates in the extension service. But, being with in middle income category does not significantly influence status of farmers' participation in the service.

* Assess to social networks: Farmers access to social networks such as Dabo, Iqoub, Iddir, Mahiber, and others were considered as factors influencing farmers' decision to participate in the extension service. Access to the association is represented by 1 while lack of access to it by 0 . As expected, the responses reveal that access to social network has positive effect on the households' participation in the service. This is because social networks help farmers to meet and acquire knowledge, skill and become aware about the type of extension services provided in the area.

* Experience in extension service: This variable is among continuous explanatory variables measured in terms of number of years households were participating in the service. It is believed that farmers' previous exposure and use of extension service significantly determines their participation in the service. Like studies such as Etwire et al. (2013) and (Dube, 2017), this finding shows positive link between households' experience of extension service and their participation indicating long term positive effects of the extension service exposure.

* Family Size: Contrary to the expectation, this study shows that there is negative relationship between family size and household's participation in extension service. This might be due to the fact that family member who have attained maturity age is responsible for his own life. This is combined with the shortage of land in the area which enforces number of youth to move to other areas particularly to cities and make household heads busier to take part in the training and other extension services.

- DAs behavior: DAs behavior in this case refers to the politeness of DAs that they reflect when having contact with and providing extension service to the rural farmers. It was represented by 0 for no polite (misbehavior) and 1 for politeness of DAs. The response shows that the more DAs are polite, the more the farmers decide to participate in the extension services.

Table 5: Marginal effect result of households' degree of participation in extension services

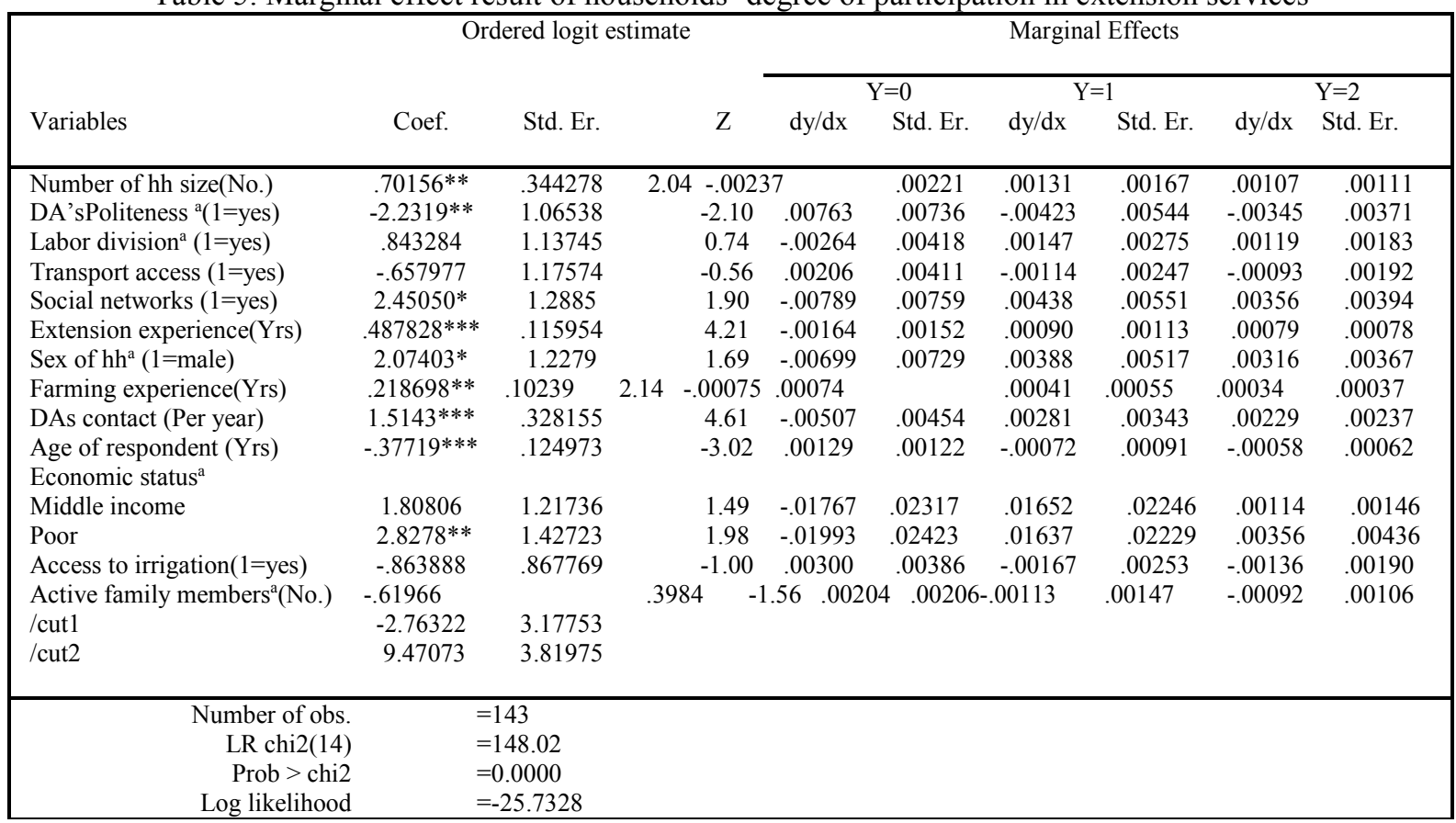

Notes: $* * *$ Significant at $1 \%, * *$ Significant at $5 \%, *$ Significant at $10 \%$ level of confidence, and

(a) dy/dx is for discrete change of dummy variable from 0 to 1

Source: Field Survey, 2018

According to the marginal affect described above, an estimated positive coefficient for a category indicates that a change (increase or decrease) in the variable by one unit (marginal) increases or decreases the probability of 
being falling with in that category. In principle, the ordered logit model with ' $j$ ' categories has ' $j$ ' sets of marginal effects and ' $\mathrm{j}-1$ ' intercepts. In this case, since the model has three categories, never participate( $\mathrm{Y}=0)$, sometimes participate $(Y=1)$, and frequently participate $(Y=2)$, the result has three marginal effects and two intercepts. The marginal effect reveals that an increase by a onetime contact of farmers by DAs decreases the probability of falling within the never participating category by $0.507 \%$ and increases the probability of falling with in the category of sometimes participating and frequently participating by $0.281 \%$ and $0.229 \%$ respectively. With regard to farming experience, a one year more farming experience of the household head is associated with decrease in the probability of the household head's falling with in the category of never participating by $0.075 \%$ while it increases the probability of falling with in the category of sometimes and frequently participating by $0.041 \%$ and $0.034 \%$ respectively holding other variables in the model at their means. Concerning age of households, a one year more in household head age from the mean increases the probability of farmer household's falling with in the category of never participating by $0.13 \%$ where as it decreases the probability of falling within the category of sometimes and frequently participating in extension service by $0.072 \%$ and $0.058 \%$ respectively. Among the categorical variables, taking female household head as base case, male household head is associated with a decrease in the probability of the household falling with in the category of never participating by $0.699 \%$, and increases the probability of falling with in the category of sometimes participating and frequently participating by $0.388 \%$ and $0.316 \%$ respectively. This is consistent with the study conducted by Mogues et al. which shows that differences in extension service accessibility between men and women in Ethiopia exists (Mogues et al., 2010). Concerning economic status, taking better-off as base case, a shift of a household from better-off to poor economic status, decreases the probability of falling with the category of never participating by about $2 \%$. But, it increases the probability of falling with the category of some times and frequently participating by $1.6 \%$ and $0.35 \%$ respectively. This shows that the higher the economic status, the more the household head is participating in extension service. The reason for low participation in extension service of the poor could be because poor households do not have finance capacity to repay for the credit services and other agricultural inputs.

\subsubsection{Major Sources of Information about Extension Services}

Provision of extension services depends on access to information and knowledge about the agricultural extension services provided by stakeholders. Though, in most cases, information is disseminated through government actors (extension workers), other sources of information including social networks, neighbors, media and model farmers do have great role in disseminating information. Table 6 below depicts major sources of information through which small holder farmers in the study area get information about the services.

Table 6: Sources of information about extension services in the area

\begin{tabular}{|l|c|c|c|c|c|c|}
\hline Source of information about extension Services & \multicolumn{3}{|c|}{ Response } & \multicolumn{4}{c|}{ Freq. } \\
\cline { 2 - 7 } & Yes & No & Total & Yes & No & Total \\
\hline Relatives/neighbors & 131 & 12 & 143 & 91.61 & 8.39 & 100 \\
\hline Development agents & 136 & 7 & 143 & 95.1 & 4.9 & 100 \\
\hline Kebele administration & 117 & 26 & 143 & 81.82 & 18.18 & 100 \\
\hline Woreda administration & 54 & 89 & 143 & 37.76 & 62.24 & 100 \\
\hline NGOs & 15 & 128 & 143 & 10.49 & 89.51 & 100 \\
\hline Mass media(TVs, radio, newspaper) & 85 & 58 & 143 & 59.44 & 40.56 & 100 \\
\hline Social networks (Iddir, Iqoub, Mehiber, Dabo) & 124 & 19 & 143 & 86.71 & 13.29 & 100 \\
\hline Model farmers & 63 & 80 & 143 & 44.06 & 55.94 & 100 \\
\hline
\end{tabular}

Source: Field survey, 2018

According to the response, about $95.1 \%$ of the households believe that the leading source of information from where rural households receive message is through development agents. Farmers' visit by extension advisors play great role for information dissemination. In fact, this raises the question why the agricultural productivity (food security) in the country could not be achieved though government has deployed extension advisors to each Kebeles. The reason could be the fact that extension service field demonstration has been ineffective. In addition, other sources of information such as relatives, social networks (Iddir, Iqoub, Dabo, Mehiber), Kebele administrations, and mass media (TVs, radio, news paper) have been contributing to provide information. In Ethiopia, informal institutions such as Iddir (social welfare services), Iqoub (rotating saving for members), Mehiber or Sanbate (church associations), Dabo (working together), and others are among basic sources through which information about extension service has been disseminated. The table describes that about $86.71 \%$ of the households agree that social network has contribution for sharing information among rural community while $13.29 \%$ of them do not agree. Mass media also contributes significant role in disseminating information about extension service at the grass root. Of the total respondent households, 85(59.44\%) agreed with its important role while 581(40.56\%) do not agree. Farmers suggested that radio plays a leading role in disseminating information to the farming community. Nevertheless, still mass media coverage in extension service provision is les as compared to other countries like Tanzania where majority of farmers $(96.3 \%)$ used radio to access information about farming systems (Lwoga et 


\section{al., 2011).}

The table also describes the role that NGOs contribute in information dissemination at grass root. Basically, NGOs are major catalysts and plays essential role for advocacy, learning, circulating information among rural community and with government sectors (FAO, 2005). For instance, in Ghana, NGOs promote technology transfer to farmers, facilitate knowledge and exchange of ideas about extension service by organizing seminars, workshops and conferences and sponsor mass communication programmes, and then disseminate to the rural farmers especially on radio and television (Villars, 1999). In contrary to the expectation, the role that NGOs are playing in the study area has been weak. The role of NGOs, Woreda administration, and model farmers' contribution has been less indicating that designing means of encouraging those actors to contribute their role is crucial. Like in field demonstration, model farmers' contribution in disseminating information has been low. In Ethiopia, the information and new technologies originating in research institutions are first communicated to model farmers who then are supposed to provide messages to the rest farmers. The best practices developed and used by model farmers is scaled-up to other areas through experience sharing. However, more than half (55.94\%) of the sample households disagree with the role of model farmers in sharing information as compared to other sources. Of the sample households, about $57.34 \%$ of them argued that model farmers' contribution in transferring knowledge and influencing life of other farmers is insignificant in the study area. This tells us that the role and contribution of model farmers in disseminating information to the rest of farmers has been low when evaluated in terms of the government target.

\subsubsection{Agricultural Extension Service Field Demonstration}

The extension service field demonstration approach in Ethiopia is a kind of three combinations; model farmers, FFS, and group-farmers approaches. The field demonstration is a means to apply extension service where DAs provide practical application of the services/training and develop new technologies. Field demonstration, whether on farm or at FTC, is considered as an alternative way of applying Farmers Field School extension service. The extension service is called Participatory Extension Service (PES) with an aim to use group training and demonstration via promoting the scaling-up of technologies and best practices (Leta et al., 2017). Nevertheless, applicability of the on farm as well FTC field demonstration in the study has visible limitations. Table 7 below depicts respondents' view about their participation in the field demonstrations in the study area.

Table 7: The status of agricultural extension service demonstration

\begin{tabular}{|c|c|c|c|c|c|}
\hline S.No. & Means of applying field demonstration & Response & Freq. & Percent & Cum. \\
\hline \multirow[t]{4}{*}{1} & \multirow{4}{*}{$\begin{array}{l}\text { Demonstration at Farmers Training } \text { Centers (FTCs) } \\
\text { approach of extension service provision. }\end{array}$} & Never & 19 & 13.29 & 13.29 \\
\hline & & Sometimes & 117 & 81.82 & 95.10 \\
\hline & & Frequently & 7 & 4.90 & 100.00 \\
\hline & & Total & 143 & 100.00 & \\
\hline \multirow[t]{4}{*}{2} & \multirow{4}{*}{$\begin{array}{l}\text { Farmer's on farm demonstration as an approach of extension } \\
\text { service provision. }\end{array}$} & Never & 89 & 62.24 & 62.24 \\
\hline & & Sometimes & 54 & 37.76 & 100.00 \\
\hline & & Frequently & 0 & 0 & \\
\hline & & Total & 143 & 100.00 & \\
\hline \multirow[t]{4}{*}{3} & \multirow{4}{*}{$\begin{array}{l}\text { Model farmers farm visit as an approach of extension } \\
\text { service provision. }\end{array}$} & Never & 113 & 79.02 & 79.02 \\
\hline & & Sometimes & 30 & 20.98 & 100.00 \\
\hline & & Frequently & 0 & 0 & \\
\hline & & Total & 143 & 100.00 & \\
\hline
\end{tabular}

Source: Field survey, 2018

The study shows that out of the 143 respondents, only 7(4.9\%) of them argued that they frequently participate in demonstration at FTCs whereas more than 117(81.82) replied as sometimes participate. On the other hand, $19(13.29 \%)$ of them stated that they have never participated in the demonstration at FTCs. The response of key informants also shows that lack of appropriate and sustainable field demonstration at FTCs is among major challenges facing the agricultural development endeavors. Though FTCs were built long years ago, the researcher observed during field work that in most of the FTCs there were no basic equipments. In principle, one FTC has to be constructed within each Kebele (lowest administrative unit) used to train and graduate at least 180 farmers per year who in turn are expected to act on behalf of DAs to transfer knowledge to the rest of farmers. This is missed in all sampled Kebeles (Interview with agricultural office head, 24/11/2018). The table also depicts that the status of field demonstration implementation at farmer's own farm visit by DAs has been hardly effective. Of the total sample households, about $89(62.29 \%$ ) of them suggested that they never had farm demonstration on their own farm. And also none of respondents argued that he/she has been frequently practicing demonstration at own farm. The third means of applying field demonstration is provision of extension service using model farmers' used to scaling-up of best practices, and sharing new technologies to farmers. In this case, extension agent works with successful and exemplary farmers who then are supposed to pass extension messages, i e., new technologies and information on to follower farmers (Kaleb et al., 2016). But, the figure above depicts that majority (79.02\%) of 
the selected respondents have never opted in model farmers farm visit whereas about $21 \%$ of the them sometimes participate. Moreover, no sample household respondent responded as frequently participating in model farmers' farm visit. Hence, practicability of scaling-up good practices from model farmers to the rest of farmers at grass root level has been weak. This is partly due to the fact that selection of model farmers is often not based solely on farming skills and social capital but includes political considerations (Lemma, 2007).

To sum up, the field survey shows that agricultural extension service field demonstration in the study area has been ineffectiveness. The extension service is primarily engaged in technology adoption than focusing in creating knowledge, innovation and demonstration at FTCs. The approach is supply-driven where the development agents control transferring technologies adopted from agricultural researches, and largely delivered by stateplanned mobilization and campaign efforts (Leta et al. 2017). According to the interview conducted with key informants, major problems of the existing field demonstration (at FTC, model framers, and own farm) in the Districts are summarized as follows (Interview with agricultural office head, 24/11/2018). First, the approach is characterized by supply-driven approach. There is lack of participatory (inclusive) and demand-based extension service approach that could ensure rural farmers participation in the planning, implementation and evaluation of extension service provisions. Inputs distributed from higher levels do not consider the local context, environment, and whether condition. For instance, in the year 2018, it was tried to apply variety of maize production but totally failed because of the whether condition. Second, there have been no continuous and regular field demonstration practices at FTC and model farmers' farm through which rural farmers could have participated and experience new technologies. Lack of adequate budget and necessary equipments used for demonstration and technology transfer was reported as the main reason for its inapplicability (Interview with DA, 25/11/2018). It is also argued that FTCs has been serving not only as a place of field demonstration for agricultural activities but also used for meeting and training particularly for social and political purposes. FTCs and Kebele administration offices often used election campaign and other activities. Third, the contribution of research centers and universities in the adoption of new technologies has been weak. No identification of farmers' demand in finding research outputs and its dissemination to rural farmers. Related to this, there is lack of relevant communication technologies and appropriate utilization of available information. Fourth, weak contact of DAs with farmers households. There is no mechanisms through which extension agents (DAs) can be responsible to the service they render and accountable to the farmers. In effect, it is difficult to control and supervise the work off DAs. Partially, it is due to lack of qualified and sufficient human power (DAs) with necessary specialization. It was observed that on job training, appropriate planning, monitoring and evaluation system in the Woreda rural and agricultural office has been lacking. In addition, there have been poor good motivation or incentive mechanisms for development agents and the agricultural office staffs. These all led DAs not to effectively contribute their role in realizing implementation of field demonstration. Fifth, lack of adequate support and extension services (access to credit, market and inputs) for diversified and multi-cropping strategies such as for vegetable and fruits in the Woreda. Inadequate funding and lack of rural financial institutions to provide credit necessary for purchasing of agricultural inputs and adoption of new technologies were limiting farmers' effort to diversify their farming activities.

\section{CONCLUSION AND POLICY IMPLICATIONS}

The existing agricultural extension service has both policy formulation and implementation gaps. The service approach needs to be considered in such a way to renovate the top-down-supply driven to participatory and clientdemand based extension service approach. For this, policy makers need to revisit the extension service.

$>$ In the extension service provision, significant number 19 (13.29\%) of sampled households never participated while majority $110(76.92 \%)$ of them sometimes participate in the use of the extension service. The main problem of the service is related to its top-down service approach. Farmer households' role has been limited to receive training delivered by DAs and have less contribution to create new ideas, knowledge, and adoption of new technologies. So, extension service DAs role and accountability has to be combined with rural farmers' contribution.

$>$ Among the major factors determining frequency of use of extension service, institutional factors such as DAs contact with farmers, DAs behavior, household's economic status, and farmers' social networks were identified. Addressing problems related to DAs contact with farmers and their behavior when giving service for farmers requires government's attention. Concerning sex of household heads, men do have higher probability of frequently participating in the extension service than women households. Hence, framing means of encouraging women farmers and realizing their benefit in the use of extension service is important.

$>$ The finding shows that farmers' access to social networks such as Iddir, Iqoub, Mahiber, Dabo, etc significantly determined households' participation in extension service. Promoting social network organizations at zone and development team level in Kebeles could contribute to increase farmers' use of the extension services.

$>$ The extension service is weak in terms of field demonstration and technology transfer. It is advisable to make the extension service more demonstration oriented at farmers' farm visit, FTCs, and model farmers scaling up of best practices. Though FTCs were built long years ago, in practice, they have been hardly functional. Even 
they do not have necessary equipments, and farming inputs necessary to develop new technologies. In addition, the role of model farmers in transferring knowledge and scaling-up best practices is ineffective. More than half of the respondents argue that model farmers were not playing their role in transforming the livelihood of rural smallholder farmers through the intended scaling up and sharing of experiences. Model farmers have neither used to disseminate information nor used to expand the intended scaling up of best practices in the area. So, it needs to evaluate effectiveness and contribution of model farmers. Revisiting policies related to model farmers such as ways of selection, structure, contribution, and government's support could be the solution to decide whether to adopt new one or modify the existing.

$>$ The finding shows that access to information and its dissemination about the extension service has been weak in the study area. Among the major sources of information, DAs contact with farmers, information from relatives/neighbors, farmers' social networks, Kebele administration, and mass media's contribution were significant. But, the contribution of NGOs, Woreda administration, and model farmers' were found to be weak. Though the number of NGOs and private sectors has been increasing, their contribution as a source of information has been limited. To promote participation of private and NGOs particularly local NGOs, government better frame legal grounds through which these stakeholders could involve in providing agricultural extension service.

\section{REFERENCES}

Adugna, Eneyew (2013). Untied efforts: The challenges for improved research, extension and education linkages. Educational Research and Reviews, Vol. 8(12).

Anderson, R, Mikuliç, Vermeylen, G, Lyly-Yrjanainen, M, Zigante (2009). Second European Quality of Life Survey: Overview. Luxembourg: Office of Publications of European Communities.

Asres, E, Makoto N. Kumi Y. Akira I. and Arega D. (2014). The Effect of Agricultural Extension Service on the Technical Efficiency of Teff Producers in Ethiopia. American Journal of Applied Sciences, Vol.11 (2): 223239.

Benson, A and Jafry, T (2013). Reaching Rural Women: Understanding the Term Gender Sensitivity in Agricultural Extension. American International Journal of Social Science Vol. 2 (5).

Berhanu, Abeje (2009). The Ethiopian Extension and the Farmer: A View from the Farm. Proceedings of the $16^{\text {th }}$ International Conference of Ethiopian Studies. A.A, Ethiopia

Berhanu, Nega W., Joseph A. Kwarteng and Ernest L. Okorley (2014) Farmers' Perception of their level of Participation in Extension in Ethiopia: Policy Implications. Journal of Agricultural Extension and Rural Development, Vol.6, No. 2.

Bieri, Sabin and Sancar, Annemarie (2009). Power and Poverty: Reducing Gender Inequality by Ways of Rural Employment? Interdisciplinary Centre for Gender Studies, FAO and FIAT.

Creswell, J.W (2007). Qualitative Inquiry and Research Design: Choosing Among Five Approaches (3 ${ }^{\text {rd }}$ Ed.). Thousand Oakes, CA: Sage

Dube, Lighton (2017). Farmer to farmer extension approach: Analysis of extent of adoption by smallholder farmers in Manical and and Masvingo provinces of Zimbabwe. Journal of Agricultural Economics and Rural Development, Vol. 3(1), pp. 149-160.

Elias, A., M. Nohmi, K. Yasunobu, and A. Ishida (2015). Farmers' Satisfaction with Agricultural Service and Its Influencing Factors: A Case Study in North West Ethiopia. Journal of Agriculture, Science and Technology, Vol. 18

FAO (2005). Improving Information Flows to the Rural Community. Agricultural Management, Marketing and Finance Occasional Paper. Rome. Italy

FAO (2011). Ethiopia Country Programming Framework (2012-2015). A.A, Ethiopia. FAO (2011). The State of Food and Agriculture 2010-11: Women in Agriculture. Rome Italy FAO (2013). World Food and Agriculture Statistical Yearbook. Rome, Italy

FAO (2017). The 2030 Agenda and the Sustainable Development Goals: The Challenge for Aquaculture Development and Management, Fisheries and Aquaculture (Circular No. 1141). Rome, Italy

Firafis, Haile (2016). Factors Affecting Women Farmers' Participation in Agricultural Extension Services For Improving The Production In Rural District Of Dendi West Shoa Zone, Ethiopia. International Journal of Research in Applied, Natural and Social Sciences. Vol.4 (7). Pp133-148

International Food Policy Research Institute (IFPRI) (2010). A review of Empirical Evidence on Gender differences in Non-land Agricultural Inputs, Technology, and services in Developing countries available online via http://demo.indienvironmentportal.org.in/files/Nonland\%20pdf20 Nov, 2017.

Kaleb, K. Ayele (2016). Analysis of the Characteristics of Model Farmers in the Ethiopian Agricultural Extension System. International Journal of Agricultural Extension.

Lemlem, Abebe (2016). Determinants of Intra-Household Gender Difference in Access to Agricultural Extension Service on Improved Maize Variety: The Case of Toke-Kutaye District, Oromia Regional State, Ethiopia. 
Unpublished MSc Thesis.

Lemma, M.(2007). The Agricultural Knowledge System in Tigray, Ethiopia: Recent History and Actual Effectiveness. Weikersheim, Germany: Margrave Publishers.

Leta G., Kelboro G, Stellmacher T, Hornidge A-K (2017). The Agricultural Extension System in Ethiopiaoperational setup, challenges and opportunities (Working paper 158), ZEF Series.

Lwoga, E. T., Stilwell, C., \& Ngulube, P. (2011). Access and Use of Agricultural Information and Knowledge in Tanzania. Library Review, 60(5), 383-395.

Mengistie, Mossie and Belete Meseret (2015). A review on the role of extension service for agricultural transformation with particular emphasis on Ethiopia. Global Journal of Agricultural Economics, Extension and Rural Development, Vol. 3, No. 1.

Ministry of Agriculture and Rural Development (MoARD) (2010). Ethiopia's Agricultural Investment Framework (PIF) 2010-2020. Report, MoARD, A.A, Ethiopia

Mogues, Tewodaj, Marc J. Cohen, Regina Birner, Mamusha Lemma, Josee Randriamamonjy, Fanaye Tadesse and Zelekawork Paulos (2010). Agricultural Extension in Ethiopia through A Gender and Governance Lens (Discussion Paper No. ESSP No.007). Ethiopia Strategy Support Program 2 (ESSP2) International Food Policy Research Institute.

Soltani, Sh.; A. Ahmadpour; S. Feali (2011). Factors Influencing Rural Women Participation in Agricultural Extension Programs, Case Study Mazandaran, Iran. International Journal of Agricultural Science and Research, Volume 2, Number 4.

Umar, Sulaiman, Phillip O.O, Hajara S., Patience K, Ismaila W (2015). Factors Influencing Level of Satisfaction with Growth Enhancement Support Scheme among Farm Families in Kaduna State, Nigeria. Journal of Agricultural Extension, Vol.19(1).

Villars, John (1999). The Role of International and Non-Governmental Organizations in Information Support for Agricultural Policy Formulation in Ghana. Study Report.

Wasihun, Berhanu, Joseph A. Kwarteng and Ernest L. Okorley (2014). Farmers' perception of their level of participation in extension in Ethiopia: Policy implications. Journal of Agricultural Extension and Rural Development. Vol.6 (2), pp. 80-86.

World Bank. (2015). SME Finance in Ethiopia: Addressing the Missing Middle Challenge (Working Paper 96365), Washington DC: World Bank.

Yenesew, Sewnet, Edo Elemo and Dereje Derso (2016). A Review of Agricultural Research, Extension and Farmers Linkage in Ethiopia. Agriculture and Biology Journal of North America https://www.researchgate.net/publication/301788621accessed April,2018 